\author{
Н. Чернуха, \\ професор кафедри соціальної реабілітації та соціальної педагогіки \\ Київського національного університету імені Тараса Шевченка, \\ доктор педагогічних наук, професор \\ nm_chernukha@ukr.net
}

ORCID iD 0000-0003-2184-7406

\title{
А. Слабковська,
}

здобувач кафедри соціальної реабілітації та соціальної педагогіки Київського національного університету імені Тараса Шевченка

flower225@meta.ua

ORCID iD 0000-0003-4483-0623,

\section{СОЦІАЛЬНА ВІДПОВІДАЛЬНІСТЬ ЯК СУЧАСНА НЕОБХІДНІСТЬ ДЛЯ БАТЬКІВ-УСИНОВИТЕЛІВ}

У статті узагальнено наукові роботи щодо соціальної відповідальності, розглянуто ії структуру. Визначено два основні типи - реальна і потенційна. Метою публікації є узагальнення результатів дослідження з тематики соціальної відповідальності, виокремлення основних особливостей соціальної відповідальності батьків-усиновителів. Репрезентовано систему заходів щодо охорони дитинства в Україні, яка передбачає визначення основних правових, економічних, організаційних, культурних та сочіальних засад щодо охорони дитинства, удосконалення законодавства про правовий і сочіальний захист дітей, приведення його у відповідність з міжнародними правовими нормами у чій сфері. Зроблено висновок про те, що наявність соціальної відповідальності батьків-усиновителів є запорукою стратегічних і тактичних цілей процесу усиновлення.

Ключові слова: сочіальна відповідальність, усиновлення, батьки-усиновителі, реальна соціальна відповідальність, потенційна сочіальна відповідальність.

() Чернуха Н., Слабковська А. 2020

○ Київський університет імені Бориса Грінченка, 2020

Останнім часом ми можемо спостерігати суттєві зміни у соціальному житті суспільства, які роблять акцент на проблемі виконання батьками обов'язків щодо виховання своїх дітей. Перед соціальною наукою і практикою постала проблема контролю батьківських обов'язків у сучасному світі, враховуючи кількість розлучень, або постійною роботою обох батьків (або одного). Враховуючи названі нюанси, можемо сказати, що з'являється проблема приділення недостатньої уваги навчанню і вихованні дітей. Саме тоді порушується традиційний лад суспільства: поява нетрадиційних сімей.

Погоджуємося з думкою, що соціальна відповідальність сучасного покоління людей виникає за зміну ідеології функціонування суспільства, за зміну підходів в споживанні ресурсів сьогодні заради перспектив існування та розвитку людства в майбутньому. Саме усвідомлення та застосування соціальної відповідальності робить можливим зміну ідеології і пріоритетів у способі життя людини та виробництві матеріальних благ з відмовою від цілей і стандартів суспільства споживання 3 формуванням суспільства на принципах духовності і культури, пошуку та впровадження інноваційних ресурсозберігаючих технологій тощо. Слідування ідеології та принципам сталого розвитку обумовлює при відповідальному ставленні та запровадженні в системі управління попередження та пом'якшення глобальних криз - економічної, енергетичної, продовольчої, екологічної, антропологічної тощо (Амоша О., 2011).

Питання відповідальності громадянина перед суспільством порушувалося ще в античності. Наприклад, у працях «Держава», «Закони», «Політика» Платон стверджував, що відповідальність перед суспільством це моральний обов'язок перед державою, формуванню якого сприяють етичне виховання та філософські роздуми. Платон у своїх репрезентує нам подвійний характер відповідальності, такий як: моральний і законний (рuс. 1). 


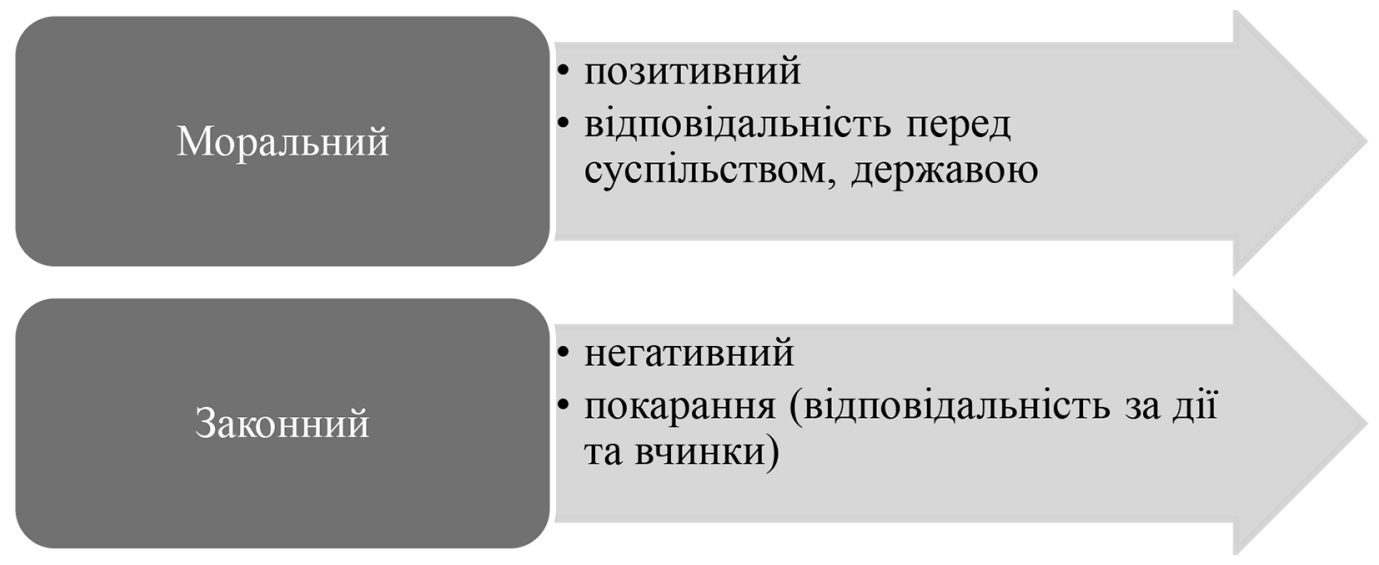

Рuc. 1. Відповідальність за Платоном

Арістотель розглядає відповідальності у контексті проблематики взаємостосунків держави та громадянина. У його праці «Політика» держава виступає як об'єднання вільних громадян, що $є$ «відносним цілим», повноцінне функціонування якого пов'язане персонально з кожним із громадян. Наголошуючи на різниці між діями та вчинками, підставою відповідальності дослідник вважає саме вчинки. Усі істоти у світі, стверджує він, виконують дії - лише людина здійснює вчинки, які у разі порушення закону характеризуються як протизаконні (Охріменко О.О., Іванова Т.В., 2015).

Аналізуючи вищесказане можемо стверджувати, ефективне керування державою буде лише тоді, коли кожен представник суспільства буде нести відповідальність не тільки перед собою, а й перед державою.

Соціальна відповідальність держави базується на iï обов'язках щодо прийняття та виконання законів, нормативних та правових документів, що спрямовані та забезпечують збереження, ефективне використання людських та природних ресурсів, додержання та реалізацію у повному обсязі державних соціальних гарантій та державних соціальних стандартів; створення умов та можливостей формування та накопичення людського та соціального капіталу (Грищук В.К, 2012).
Соціальна відповідальність - це волевиявлення, яке визначається певною поведінкою щодо дотримання усвідомлених обмежень та соціальних норм, гарантує безпеку та прогресивний розвиток, забезпечує узгодження інтересів суб'єктів, задіяних у суспільних відносинах та управлінні ними (Грищук В.К, 2012).

Соціальна відповідальність багатоаспектна та багаторівнева за своєю структурою. Вона виявляється на особистісному рівні через ступінь громадянської зрілості особистості та $є$ базовою для інших рівнів. Від світосприйняття та усвідомлення людиною своєї значущості у світових перетвореннях, від іiі прагнення до перетворень у всіх сферах своєї життєдіяльності залежать їі прояви на інших рівнях (Грищук В.К, 2012).

Метою даної публікації є узагальнення результатів дослідження 3 тематики соціальної відповідальності і виокремлення на цій основних особливостей соціальної відповідальності батьків-усиновлювачів.

Соціальна відповідальність виступає невід’ємним елементом сучасного суспільства, де вчинки і відповідальність перебувають у постійному взаємозв'яку. А отже, вважаємо за необхідне виокремити структуру соціальної відповідальності (рuс. 2).

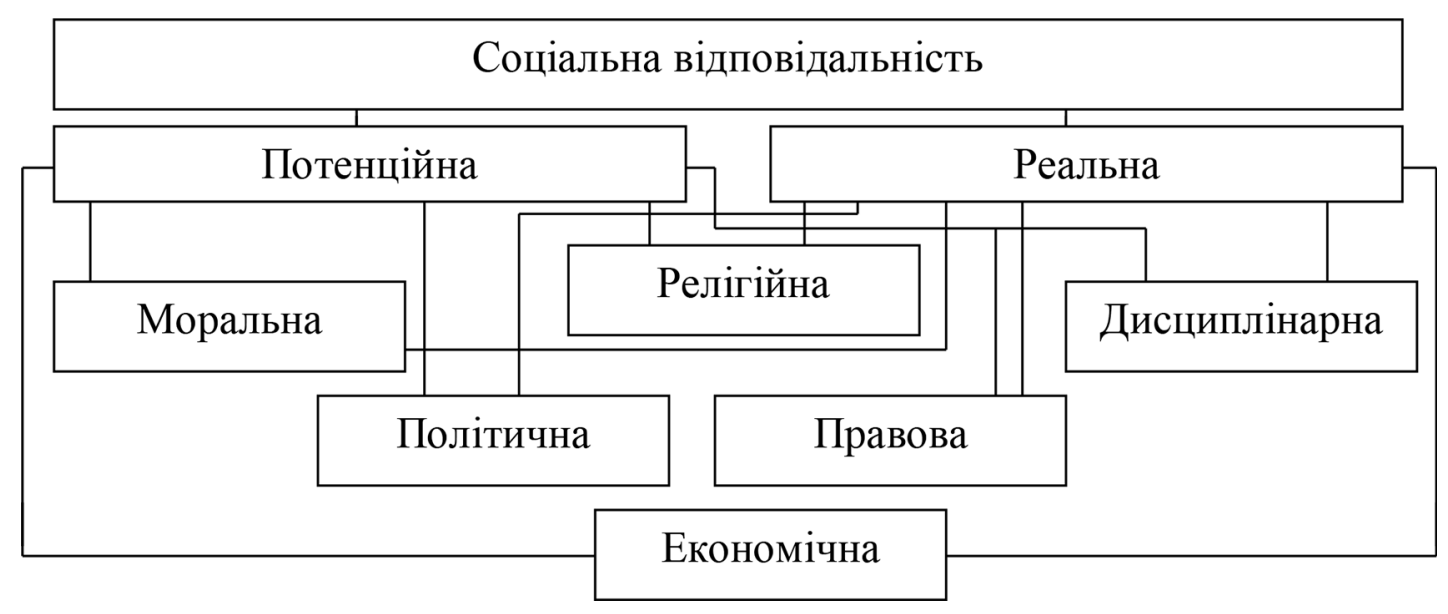

Puc. 2. Структура соціальної відповідальності 
Під реальною соціальною відповідальністю слід сприймати відповідальність 3 точки зору особистого чинника. Здійснивши певний вчинок - ти повинен усвідомити наслідки відповідно до існуючих соціальних норм. Такі наслідки можуть нести як позитивний, так і негативний характер (негативний характер відповідальності виникає через неспівпадіння зробленого з пануючими нормами суспільства.

Під потенційною соціальною відповідальністю розуміємо наявність дієвого контролю з боку суспільства, яке в свою чергу має належно регулювати всі існуючи види відповідальності, які існують у ньому. Соціальна відповідальність починається з усвідомлення особистих наслідків будь-яких дій чи вчинків кожним елементом суспільства (кожною людиною).

Маючи два основні типи (реальна і потенційна) соціальної відповідальності, виокремимо їхні основні різновиди, такі як: моральна, релігійна, дисциплінарна, політична, правова, економічна тощо. Моральна відповідальність виникає у випадку порушення традицій, звичаїв, норм культури та естетичних норм. Вона відображається у суспільному осуді та соціальному відмежуванні від суб'єкта, що порушує чи ухиляється від виконання норми поведінки. Політична відповідальність настає при порушенні норм, дотримання яких покладається суспільством на публічного політика. Корпоративна відповідальність настає у випадку порушення корпоративних правил, які прийняті певною соціальною структурою та не мають правового значення. Релігійна відповідальність засновується на нормах, що регламентують порядок відправлення релігійних культів та на вірі у Бога. Всі згадані вище види соціальної відповідальності мають пасивний характер, оскільки негативна реакція з боку суспільства у цих випадках не передбачає примусового впливу на порушника норм. Правова відповідальність настає у випадку порушення норм державно-організованого права. Вона має активний характер, оскільки передбачає активний психологічний вплив на порушника аж до застосування примусового фізичного впливу (Бахтін М., 1986).

Діти - це наше майбутнє. Нам необхідно зробити світ кращим для них, де вони будуть розвиватися, навчатися і виховуватися у безпечному для них світі. Де не буде виникати загрози насильства через інакшу думку або наявні зовнішні відмінності. Саме тоді буде сформовано ідеальне покоління, яке буде здорове і щасливе. Батькам слід розуміти, що належне виконання батьківських обов'язків допоможе змінити наступне покоління на краще, а від так батьки зможуть з гордістю знаходитися у суспільстві.

Сьогодні наше суспільство створює все можливе задля формування здорового і відповідального майбутнього покоління. Для цього уряд враховує правові, економічні, організаційні, культурні та соціальні засади для забезпечення безпеки дитинства. Сформовані правові норми в Україні відповідають міжнародним нормам захисту дітей і забезпечення їм належних умов для їхнього становлення як повноцінного члена суспільства. Наразі саме батьки повинні зрозуміти, що відсутність з їхнього боку належної опіки, виховання і навчання дітей $є$ порушенням встановлених правових норм, за які батьки будуть нести відповідальність не тільки перед собою і дітьми, а й перед суспільством і державою.

Соціальний працівник спільно з батьками усиновленої дитини, враховуючи специфіку та індивідуальні потреби особистості, вивчають можливі варіанти вирішення проблем, що виникли в процесі усиновлення, різні шляхи досягнення успіху та обирають найефективніші методи. Визначається відповідальність кожної із сторін як працівника, так і батьків, графік роботи, формулюються конкретні заходи та дати їх реалізації.

Соціальний працівник має право на контролювання виконання обов'язків батьків щодо виховання та розвитку висвітлені у статті 150 Сімейного кодексу України, а саме: батьки зобов'язані виховувати дитину в дусі поваги до прав та свобод інших людей, любові до своєї сім’'і та родини, свого народу, своєї Батьківщини, піклуватися про здоров'я дитини, iї фізичний, духовний та моральний розвиток, забезпечити здобуття дитиною повної загальної середньої освіти, готувати іiі до самостійного життя. Батьки зобов'язані поважати дитину. Передача дитини на виховання іншим особам не звільняє батьків від обов'язку батьківського піклування щодо неї. Забороняються будь-які види експлуатації батьками своєї дитини, фізичні покарання дитини, а також застосування ними інших видів покарань, які принижують людську гідність дитини (Сімейний кодекс України, 2020).

Наголосимо на тому, що для покращення якості соціальної відповідальності є необхідним покращення соціально-психологічної діагностики потенційних усиновителів та врахування особистісних характеристик (інтересів, захоплень, віку, ставлення до життя, релігійності, життєвого досвіду, рівня розвитку рефлексії, вміння приймати рішення та нести за них відповідальність, виховні уміння та навички, здатність надати захист дитині, долати важкі ситуації, будувати стабільні стосунки; емоційна теплота, комунікативні здібності) та знання специфіки розвитку дітей-сиріт та дітей, позбавлених батьківського піклування (Безвесильная А.А., 200).

Саме тому і створюються спеціальні групи, до складу яких входять різноманітні групи спеціалістів системи соціально-педагогічної роботи, які виконують певні функції: керівник, соціальний блок, психологічний блок, педагогічний блок. На основі інформації про усиновлену дитину 
складається індивідуальний сімейний план соціально-педагогічної роботи, де окремо визначаються завдання кожного спеціаліста.

Наголосимо, що саме означений вид колаборації різноманітних установ дають змогу підвищити якість соціальної відповідальності батьківусиновителів. Створивши безпосередньо такий консиліум, поліпшується робота 3 батьками, навіть дистанційно. Батьки-усиновителі беруть активну участь у корекційному процесі, виконують $з$ дитиною запропоновані на певний період завдання, отримують різноманітні консультації щодо проблем усиновленої дитини, організації розвиваючого середовища вдома. Розуміння того, що вони відповідають не лише перед соціальним педагогом, а перед усіма спеціалістам та адміністрацією закладу, формує у них більшу відповідальність за свої слова та вчинки, зацікавленість розвитком своєї дитини.

Висновок. Усиновлювачам треба принципово усвідомити, що усиновлена ними дитина має такі ж соціальні, емоційні та фізичні необхідності, як і будь-яка дитина у повноцінній сім'ї. Украй важливим $€$ усвідомлення процесу виникнення цих необхідностей і розуміння шляхів їх задоволення, особливо якщо ці необхідності на початковому етапі протирічать культурним нормам усиновлювачів.
Ніякі форми влаштування окрім усиновлення не дають змоги суспільству подолати сирітство, як соціальне явище. Соціальне батьківство й материнство має таке ж право на існування, як біологічне. Соціальне батьківство передбачає передачу батьківської відповідальності біологічно не рідним дорослим над дитиною на правах сина чи дочки за спеціальним рішенням суду.

Виконуючи свої обов'язки як батьків-усиновителів потрібно пам'ятати, що будь які їхні дії повинні опиратися на повагу до дитини та їі гідності. Не слід забувати батькам і те, що інтереси батьків повинні завжди бути пов'язаними 3 інтересами дитини. Сьогоднішні норми суспільства засуджують відмову від дитини за будь-яких умов. Саме тому з'являється відповідальність батьків перед суспільством і державою на законодавчому рівні.

А отже, своєчасність соціальної відповідальності батьків-усиновителів $€$ запорукою стратегічних і тактичних цілей даного процесу. Несвоєчасна соціальна відповідальність, а тим більше іiі відсутність, істотно послаблює ресурс нормативності суспільних відносин, розбалансовує усталені механізми соціального контролю, може провадити до анархічності, непрогнозованості, несталості, охлократії, аномії суспільства як цілісної системи або і знищення їі в цілому.

\section{ДЖЕРЕЛА}

1. Амоша О. Соціальна відповідальність в контексті розвитку людського потенціалу. Держава $і$ суспільство. 2010. С. 122-27. URL: http://www.nbuv.gov.ua/portal/soc_gum/pubupr/2011-1/doc/3/01.pdf 2. Баюра Д.О. Формування системи корпоративного управління на засадах соціальної відповідальності. Вісник Київського національного університету ім. Т. Шевченка. Серія: Економіка. 2013. № 10. C. $18-22$.

3. Безвесильная А.А. Информационные технологии в профессиональной деятельности социального педагога. Среднее профессиональное образование. 2008. № 11. С. 19-22.

4. Байєр О. Особливості формування соціальної впевненості дитини. Практичний психолог: дитячий садок. 2013. № 3. С. 25-26; № 4. С. 45-51.

5. Вигонна В. Посвята в батьки: тренінг батьківської ефективності. Психолог довкілля. 2012. № 7. C. 20-22.

6. Грищук В.К. Соціальна відповідальність: навч. посіб. / Львівський університет внутрішніх справ, Львів, 2012. 152 с.

7. Сімейний кодекс України від 03.07.2020 p. URL: https://zakon.rada.gov.ua/laws/show/2947-14\#Text 8. Охріменко О.О., Іванова Т.В. Соціальна відповідальність: навч. посіб. / Національний технічний університет України «Київський політехнічний інститут». Київ, 2015. 180 с.

9. Перші запитання про сина і доньку. Путівник для майбутніх усиновителів, прийомних батьків та опікунів. К.: Логос, 2007. 47 с.

10. Ревть А., Гриник I. Особливості соціально-педагогічної роботи з профілактики насильства щодо дітей. Молодь і ринок. 2019. № 1 (168). С. 33-36. DOI: https://doi.org/10.24919/23084634.2019 .158316

\section{REFERENCES}

1. Amosha, O. (2010). Sotsialna vidpovidalnist v konteksti rozvytku liudskoho potentsialu [Social Responsibility in the Context of Human Development]. Derzhava i suspilstvo, pp. 122-27 (in Ukrainian). http://www.nbuv.gov.ua/portal/ soc_gum/pubupr/2011-1/doc/3/01.pdf 
2. Baiura, D. O. (2013). Formuvannia systemy korporatyvnoho upravlinnia na zasadakh sotsialnoi vidpovidalnosti [Formation of Corporate Governance Principles for Social Responsibility]. Visnyk Kyivs'koho natsionalnoho universytetu im. Tarasa Shevchenka, Seriia «Ekonomika», № 10, pp. 18-22 (in Ukrainian).

3. Bezvesilnaia, A. A. (2008). Informatsionnyie tekhnologii v professionalinoi deiatelnosti sotsalnogo pedagoga [Information Technologies in the Professional Activity of a Social Teacher]. Srednee professionalnoie obrazovanie, № 11, pp. 19-22 (in Russian).

4. Bajyer, O. (2013). Osoblyvosti formuvannia sotsialnoi vpevnenosti dytyny [Features of Formation of Social Confidence of the Child]. Praktychnyi psykholoh: dytiachyi sadok, № 3, pp. 25-26; № 4, pp. 45-51 (in Ukrainian).

5. Vyhonna, V. (2012). Posviata v batky: treninh batkivskoi efektyvnosti [Dedication to Parents: parenting effectiveness training]. Psykholoh dovkillia, № 7, pp. 20-22 (in Ukrainian).

6. Gryshchuk, V. K. (2012). Sotsialna vidpovidalnist [Social Responsibility]. Navchalnyi posibnyk, Lvivskyi universytet vnutrishnikh sprav, Lviv, 152 p. (in Ukrainian).

7. Zakon Ukrayiny (2020). «Simeinyi kodeks Ukrainy» vid 03.07.20 [The Family Code of Ukraine dated 03.07.20]. (in Ukrainian).

https://zakon.rada.gov.ua/laws/show/2947-14\#Text

8. Okhrimenko, O. O., Ivanova, T. V. (2015). Sotsialna vidpovidalnist [Social Responsibility]. Navch.posib., Natsionalnyi tekhnichnyi universytet Ukrainy «Kyivskyi politekhnichnyi instytut», 180 p. (in Ukrainian). 9. Pershi zapytannia pro syna i donku. (2007). [A Guide for Future Adoptive Parents, Foster Parents and Guardians]. Putivnyk dlia maibutnikh usynovyteliv, pryiomnykh batkiv ta opikuniv, K.: Lohos, 47 p. (in Ukrainian).

10. Revt, A., Grynyk, I. (2019). Osoblyvosti sotsialno-pedahohichnoi roboty z profilaktyky nasylstva shchodo ditei [Features of Socio-Pedagogical Work on the Prevention of Violence against Children]. Molod i rynok, №1 (168), pp. 33-36 (in Ukrainian).

DOI: https://doi.org/10.24919/2308-4634.2019.158316

\section{Н. Чернуха, А. Слабковская СОЦИАЛЬНАЯ ОТВЕТСТВЕННОСТЬ КАК СОВРЕМЕННАЯ НЕОБХОДИМОСТЬ ДЛЯ РОДИТЕЛЕЙ-УСЫНОВИТЕЛЕЙ}

В статье обобщены научные работы по сочиальной ответственности, рассмотрена ее структура. Выделены два основных типа - реальная и потенциальная. Целью данной публикации является обобщение результатов исследования по тематике социальной ответственности и выделение основных особенностей социальной ответственности родителей-усыновителей. Представленная система мероприятий по охране детства в Украине включает определение основных правовых, экономических, организационных, культурных и социальных основ по охране детства, совершенствование законодательства о правовой и социальной защите детей, приведение его в соответствие с международными правовыми нормами в этой срере. Сделан вывод, что наличие социальной ответственности родителей-усыновителей является залогом стратегических и тактических иелей проиесса усыновления.

Ключевые слова: социальная ответственность, усыновление, родители-усыновители, реальная социальная ответственность, потенциальная социальная ответственность.

\section{N. Chernukha, A. Slabkovska SOCIAL RESPONSIBILITY AS A MODERN NECESSITY FOR ADOPTIVE PARENTS}

The article summarises scientific work on social responsibility. It is emphasised that the social responsibility of the state is one of the mechanisms for ensuring the quality and efficiency of public administration. The functions of the state that reproduce social responsibility are represented, they include: fulfillment of international obligations, achievement of priority national interests and strategic goals of state development, formation of decent living conditions and prospects for human development, etc.

The structure of social responsibility is considered. There are two main types (real and potential) of social responsibility. Under real social responsibility should be perceived responsibility in terms of personal factors. By potential social responsibility we mean the presence of effective social control that can ensure that each perpetrator is brought to the appropriate type of social responsibility in cases of violation of social norms, and in personal - a person's awareness of responsibility for the consequences of personal activities.

The purpose of this publication is to summarize the results of a study on social responsibility and highlight the main features of social responsibility of adoptive parents. The system of measures for child protection 
in Ukraine is represented, including: determination of basic legal, economic, organizational, cultural and social principles for child protection, improvement of legislation on legal and social protection of children, bringing it in line with international legal norms in this area. It is concluded that the presence of social responsibility of adoptive parents is a guarantee of strategic and tactical goals of the adoption process. It is emphasized that untimely social responsibility, and even more so its absence, significantly weakens the resource of normative social relations, unbalances the established mechanisms of social control, can lead to anarchy, unpredictability, instability, ochlocracy, anomie of society as a whole system or its destruction.

Key words: social responsibility, adoption, adoptive parents, real social responsibility, potential social responsibility.

Стаття надійшла до редакції 16.11.2020 p.

Прийнято до друку 26.11.2020 p. 